\title{
The effects of HIV-1 subtype and ethnicity on the rate of CD4 cell count decline in patients naive to antiretroviral therapy: a Canadian-European collaborative retrospective cohort study
}

\author{
Marina B. Klein MD MSc, Jim Young PhD, David Dunn PhD, Bruno Ledergerber PhD, \\ Caroline Sabin PhD, Alessandro Cozzi-Lepri PhD, Francois Dabis MD PhD, Richard Harrigan MD, \\ Darrell H. Tan MD PhD, Sharon Walmsley MD MSc, John Gill MB MSc, Curtis Cooper MD MSc, \\ Alexandra U. Scherrer PhD, Amanda Mocroft MSc, Robert S. Hogg PhD, Fiona Smaill MB MSc; \\ for the Canadian-European Clade Collaboration
}

\section{Abstract}

Background: Ethnic differences have the potential to confound associations between HIV-1 subtype and immunologic progression. We compared declines in CD4 cell counts during untreated infection for the most prevalent HIV-1 subtypes, focusing on distinguishing between the effects of viral subtype and ethnicity.

Methods: We combined data from 4 European and 6 Canadian cohorts, selecting adults in the stable chronic phase of untreated HIV infection. We estimated the change in square root CD4 cell count over time for subtypes and ethnicities using mixed models, adjusting for covariates selected for their potential effect on initial CD4 cell count or its decline.

Results: Data from 9772 patients were analyzed, contributing 79175 measurements of CD4 cell count and 24157 person-years of follow-up. Overall, there were no appreciable differences in CD4 cell count decline for viral subtypes A, CRF01_AE, CRF02_AG, C and $\mathrm{G}$ compared with viral subtype B; whereas the decline in CD4 cell count in patients of African ancestry was considerably slower than in patients of other ethnicity. When ethnic groups were studied separately, there was evidence for slower declines in CD4 cell count in viral subtypes $C$, and possibly $A$ and $G$, compared with viral subtype B in patients of African ancestry but not among patients of other ethnicities, suggesting an interaction between subtype and ethnicity.

Interpretation: Ethnicity is a major determinant of CD4 cell count decline; viral subtype differences may have existed but were small compared with the effect of ethnicity and were most apparent in patients of African ancestry. In developing countries, slower CD4 cell count declines among individuals of African descent may translate to a longer asymptomatic phase and increase the opportunity for HIV transmission.

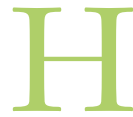
IV-1 has acquired extensive genetic diversity with 9 recognized subtypes $(\mathrm{A}-\mathrm{D}, \mathrm{F}-\mathrm{H}, \mathrm{J}$ and $\mathrm{K}$ ) and many circulating recombinant forms (CRFs). ${ }^{1,2}$ Subtype B is the most studied because it is the predominant virus in North America and Europe. Most (89\%) HIV infections worldwide, however, originate from non-subtype-B viruses, with subtypes $\mathrm{C}$ and $\mathrm{A}$ and recombinants CRF01_AE and CRF02_AG accounting for $73 \%$ of all HIV-1 infections. ${ }^{3}$ Owing to patterns of immigration, a growing number of HIV infections in developed countries are occurring in migrant communities with HIV infection resulting from viral subtypes other than subtype $B, 4,5$ with increasing transmission of subtypes between ethnicities. ${ }^{6}$ In Canada, the other subtypes now account for about $15 \%$ of newly reported HIV infections. ${ }^{7}$
CD4 cell counts are both the primary prognostic marker for HIV-related disease and the main indicator for starting antiretroviral therapy. Worldwide use of antiretroviral therapy is expanding, and it is important to understand whether differences in immunologic progression exist that might necessitate subtype-specific monitoring and treatment guidelines. Subtype-specific estimates of CD4 cell count trajectories are also essential for public health models used to predict the course of

Competing interests: See end of article.

Correspondence to: Marina Klein, marina.klein @mcgill.ca

CMAJ Open 2014. DOI:10.9778/cmajo.20140017 
the HIV epidemic and are helpful for estimating what proportion of persons born abroad acquire HIV infection in their adopted country. ${ }^{8}$

HIV-1 diversity might affect immunologic progression through differential interactions with the human host. ${ }^{9-13}$ Determining subtype-specific effects on immunologic progression is challenging: ${ }^{14}$ non-subtype-B viruses predominantly affect individuals of African descent, and several studies have suggested that rates of decline in the CD4 cell count differ according to ethnicity. Ethnic differences have the potential to confound any association between viral subtype and immunologic progression. ${ }^{15-17}$ We conducted a Canadian and European collaborative study to examine CD4 cell count decline, according to the most prevalent viral subtypes, in untreated patients who are in the stable chronic phase of HIV infection, and we focused on distinguishing between the effects of viral subtype and ethnicity.

\section{Methods}

\section{Data collection}

Ten cohorts or cohort collaborations were selected: 4 from Europe and 6 from Canada (Table 1). ${ }^{18-23}$ The project was approved by the relevant scientific boards or steering committees. EuroSIDA omitted patients also enrolled in other contributing cohorts. For each patient, we requested all available CD4 cell counts in patients enrolled in the cohort until the start of antiretroviral therapy, and the dates of any newly acquired AIDS-defining illness or death.

Seven cohorts provided information on ethnicity using a variety of classifications including race categories (e.g., black, white, Asian and Aboriginal), country of origin or a combination of the two (Table 1); therefore, ethnicity was coded as African ancestry, other ethnicity or unknown. French law does not permit the ANRS CO3 Aquitaine cohort to collect information on ethnicity or country of origin. Viral subtype was determined by the REGA HIV-1 and HIV-2 automated subtyping tool (version 2.0) based on HIV-1 pol sequences during genotypic resistance testing or, in some earlier cases, with the Subtype Analyzer tool. ${ }^{24}$

Our analysis was restricted to adults (age $\geq 16 \mathrm{yr}$ ) enrolled in the studies between January 1998 and June 2010 with a known HIV-1 subtype and at least 2 CD4 cell count measurements within 1 year while they were naive to antiretroviral therapy. We selected CD4 cell count measurements in patients

\begin{tabular}{|c|c|c|c|c|}
\hline \multirow[b]{2}{*}{ Cohort } & \multirow{2}{*}{$\begin{array}{l}\text { Co-author } \\
\text { responsible } \\
\text { for data }\end{array}$} & \multicolumn{2}{|c|}{$\begin{array}{l}\text { No. of patients contributing } \\
\text { CD4 cell counts }\end{array}$} & \multirow[b]{2}{*}{ Terminology used to assign ethnicity and region } \\
\hline & & Unselected & Selected & \\
\hline \multicolumn{5}{|c|}{ Canadian $^{18,19}$} \\
\hline Calgary & J. Gill & 79 & 62 & Ethnicity (black, white, Aboriginal, Asian, other, missing) \\
\hline Hamilton & F. Smaill & 30 & 7 & $\begin{array}{l}\text { Ethnicity (black, First Nations, white) } \\
\text { Country (no Caribbean countries for patients of African ancestry) }\end{array}$ \\
\hline HOMER & R. Hogg & 1831 & 1112 & Ethnicity (black, white, Asian, First Nations, hispanic, missing) \\
\hline Montréal & M. Klein & 346 & 196 & $\begin{array}{l}\text { Country (patient assumed to be of African ancestry if country listed } \\
\text { is Burundi, Cameroon, Congo, Democratic Republic of the Congo, } \\
\text { Ethiopia, Gabon, Guinea, Ivory Coast, Morocco, Mali, Rwanda, } \\
\text { Senegal, South Africa, Chad or Zimbabwe, or the Caribbean } \\
\text { countries of Barbados, Dominican Republic, Haiti, Jamaica, } \\
\text { Martinique or Saint Lucia) }\end{array}$ \\
\hline Ottawa & C. Cooper & 65 & 50 & $\begin{array}{l}\text { Country (patient assumed to be of African ancestry if the country } \\
\text { listed is Angola, Burundi, Congo, Ethiopia, Haiti, Rwanda, Somalia } \\
\text { or Zambia) }\end{array}$ \\
\hline Toronto & S. Walmsley & 187 & 125 & $\begin{array}{l}\text { Ethnicity (black, white, Asian, south Asian, other, missing) } \\
\text { Country (Barbados, Cuba, Dominica, Grenada, Haiti, Jamaica, } \\
\text { Trinidad and Tobago listed) }\end{array}$ \\
\hline \multicolumn{5}{|l|}{ European } \\
\hline Aquitaine ${ }^{20}$ & F. Dabis & 442 & 348 & Not available \\
\hline EuroSIDA $^{21}$ & A. Cozzi-Lepri & 349 & 267 & $\begin{array}{l}\text { Ethnicity (black, white, Asian, missing) } \\
\text { Country (no Caribbean countries for patients of African ancestry) }\end{array}$ \\
\hline $\mathrm{SHCS}^{22}$ & B. Ledergerber & 2802 & 2087 & $\begin{array}{l}\text { Ethnicity (black, white, hispanic, asian, other, missing) } \\
\text { Region (Caribbean) }\end{array}$ \\
\hline UK CHIC ${ }^{23}$ & C. Sabin & 7551 & 5518 & $\begin{array}{l}\text { Ethnicity (black, white, Indian, other, missing) } \\
\text { Country (Barbados, Bermuda, Cuba, Jamaica, Saint Kitts and } \\
\text { Nevis listed) }\end{array}$ \\
\hline
\end{tabular}


who were within a stable chronic phase of untreated HIV infection. Various strategies have been used in studies of CD4 cell count decline to exclude measurements made in the acute or late phases of infection. ${ }^{16,17,25,26}$ In this study, we omitted any patient with a first AIDS event either before or within 3 months after their first CD4 cell count measurement; these patients were likely to be late presenters. To avoid including $\mathrm{CD} 4$ cell count measurements made during acute infection, we removed measurements within 6 months of documented seroconversion (known only for $15 \%$ of patients) and measurements $<100$ cells $/ \mu \mathrm{L}$ at the beginning of a series; these measurements may reflect the rapid CD4 cell count decline that occurs immediately after seroconversion before the immune system responds to infection. To avoid including measurements made in late-stage infection, we ended a patient's series when the first of 2 consecutive measurements fell below 100 cells/ $\mu \mathrm{L}$. Consecutive measurements at both the beginning and end of the series had to be at least 2 months and no more than 12 months apart to avoid remeasurement (where a second measurement was made to check a first) or measurement prompted by clinical deterioration (where a patient lost to follow-up returned because of poor health).

\section{Statistical analysis}

Patients were followed from the time of the first CD4 cell count measurement in their series until the start of antiretro-

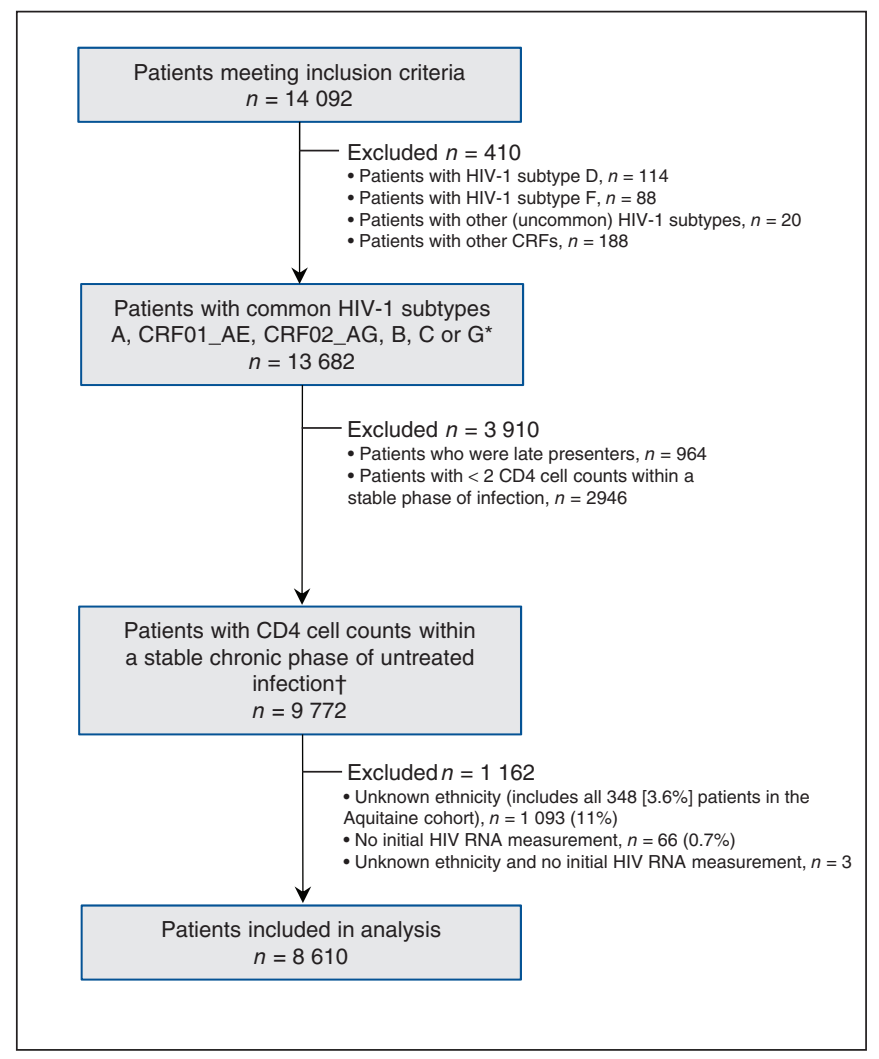

Figure 1: Selection of study cohort. *At least 100 patients available per subtype with CD4 cell counts within the stable chronic phase of untreated infection. fIncludes patients with ethnicity assigned based on country of origin, $n=246(2.5 \%)$ (Table 1$)$. viral therapy, the last CD4 cell count measurement in their series or death. In the main analysis, we compared CD4 cell counts (square root transformed to stabilize the variance) over time for the most common (at least 100 patients available) HIV-1 subtypes (A, CRF01_AE, CRF02_AG, B, C and G) using a mixed linear regression model. This mixed model included both patient-specific random intercepts and random slopes over time to allow for heterogeneity in patients' initial CD4 cell counts and subsequent declines. In the main analysis, models were adjusted for covariates selected because of their potential effect on initial CD4 cell count (age, sex, ethnicity, initial HIV RNA, injection drug use as the likely mode of transmission and cohort) or on CD4 cell count decline (age, sex, ethnicity, initial HIV RNA and injection drug use as the likely mode of transmission). In a descriptive analysis of ethnic and subtype effects, we plotted random effects representing each patient's estimated CD4 cell count decline from a mixed model without ethnicity or subtype slope parameters. We also report CD4 cell count intercept and slope estimates for each subtype from mixed models fit to untransformed data, because rates of CD4 cell count decline are easier to interpret on the original scale than on a square root scale.

We explored the results from our main analysis in a variety of sensitivity analyses. First, the main analysis model was refit to all CD4 cell counts since January 1998 without further selection (to include measurements made in both the acute and advanced stages of infection). Second, separate mixed models were fit for patients of African and other ethnicities. Third, the main analysis model was fit as part of a joint model, together with an exponential model for the time taken to start antiretroviral therapy. ${ }^{27}$ The joint model allows for informative censoring if the CD4 cell count series are shorter for some subtypes because patients with these subtypes start therapy at higher CD4 cell counts. Finally, we varied the covariates and cohorts in the analysis because not all cohorts were able to provide all covariates of interest.

Clinical events, such as time to a first AIDS-defining illness and death before starting antiretroviral therapy, were summarized according to viral subtype and ethnicity. No formal analyses were conducted because of the small numbers of events and the potential for bias due to unobserved events before cohort enrolment.

We used SAS 9.2 (SAS Institute, Cary, North Carolina) for all analyses.

\section{Results}

A total of 14092 patients met the inclusion criteria: 13682 patients had one of the subtypes A, CRF01_AE, CRF02_AG, $\mathrm{B}, \mathrm{C}$ or $\mathrm{G}$ (Figure 1). After applying CD4 cell count selection criteria, 9772 patients remained, contributing 79175 CD4 cell count measurements and 24157 person-years of followup with a median of $6 \mathrm{CD} 4$ cell count measurements per patient (interquartile range [IQR] 3-11). For most patients, CD4 cell count measurements were censored either by the patient starting antiretroviral therapy $(37 \%)$ or by irregular measurement at the end of the series (33\%), but 144 patients 
$(1.5 \%)$ reached a CD4 cell count of $<100$ cells $/ \mu \mathrm{L}$ without starting antiretroviral therapy, and 22 patients $(0.2 \%)$ died.

Subtype B accounted for most of the HIV-1 infections (81.2\%) followed by subtypes C (8.4\%), A (3.6\%), CRF02_AG (3.6\%), CRF01_AE (2.0\%) and G (1.1\%) (Table 2). The demographic and clinical characteristics of the other viral subtypes were similar, with the exception of CRF01_AE. Nonsubtype- $\mathrm{B}$ infections were found principally among patients of African ancestry, whereas subtype B and CRF01_AE infections were found among those of other ancestries. Both initial CD4 cell counts and initial HIV RNA were higher in patients with HIV-1 infections caused by subtypes CRF01_AE or B.

For the main analysis, we omitted 1162 patients because either their ethnicity or initial HIV RNA was unknown (Figure 1). Patients of unknown ethnicity had characteristics similar to those of other ethnicities (Table 3). In the main analysis, patients of African ancestry had an appreciably slower rate of CD4 cell count decline compared with patients of other ethnicities (Table 4). Differences between viral subtypes, however, were minor compared with the difference between the 2 ethnic categories. Subtype differences became apparent when the main analysis model was fit to unselected CD4 cell counts, with appreciably slower declines in cell counts in patients with viral subtypes A, C and CRF02_AG compared with patients with viral subtype B. If ethnicity was ignored in an analysis of selected CD4 cell counts, then these 3 subtypes appeared to have slower declines than patients with viral subtype B. In our descriptive analysis of ethnicity and viral subtype effects, patients of African ancestry had slower declines among all subtypes compared with patients of other ethnicities (Figure 2), including within subtype B (although no conclusion can be drawn about subtype CRF01_AE). In an exploratory analysis of patients with subtype B, patients of African ancestry from Caribbean countries appeared to have a CD4 decline intermediate between other patients of African ancestry and patients of other ethnicities (Figure 3).

In sensitivity analyses, we fit separate models for patients of African and other ethnicities (Table 4). The results from these analyses suggest little difference between subtypes in patients of other ethnicities, but patients of African ancestry with viral subtype $C$ and possibly subtypes $A$ and $G$ showed slower declines compared with viral subtype B. Only viral subtype CRF01_AG appeared to have a similar effect in both ethnic groups. This amounts to an interaction between the effects of subtype and ethnicity; however, we did not have

Table 2: Baseline characteristics of the study population by HIV-1 subtype: median or proportion of column total; numbers in parentheses represent missing observations

HIV-1 subtype

\begin{tabular}{|c|c|c|c|c|c|c|c|}
\hline \multirow{2}{*}{ Variable } & & \multirow[b]{2}{*}{ Total } \\
\hline & A & CRF01_AE & CRF01_AG & B & $\mathrm{C}$ & G & \\
\hline Total cases & 356 & 193 & 352 & 7937 & 822 & 112 & 9772 \\
\hline Age, yr, median & 34 & 38 & 34 & 35 & 33 & 33 & 35 \\
\hline Sex, female & 0.53 & 0.24 & 0.57 & 0.11 & 0.59 & 0.48 & 0.19 \\
\hline \multicolumn{8}{|l|}{ Likely mode of transmission } \\
\hline Heterosexual & 0.70 & 0.58 & 0.74 & 0.10 & 0.71 & 0.71 & 0.21 \\
\hline Men who have sex with men & 0.14 & 0.32 & 0.12 & 0.67 & 0.09 & 0.15 & 0.57 \\
\hline Injection drug use & 0.06 & 0.03 & 0.00 & 0.12 & 0.02 & 0.08 & 0.11 \\
\hline Other or unknown & 0.10 & 0.08 & 0.14 & 0.11 & 0.18 & 0.06 & 0.11 \\
\hline African ancestry & $0.49(20)$ & $0.03(13)$ & $0.60(52)$ & $0.05(973)$ & $0.72(30)$ & $0.55(8)$ & $0.15(1096)$ \\
\hline Hepatitis C co-infection & $0.10(43)$ & $0.06(18)$ & $0.03(22)$ & $0.18(1094)$ & $0.04(172)$ & $0.13(15)$ & $0.16(1364)$ \\
\hline Hepatitis B co-infection & $0.05(42)$ & $0.03(19)$ & $0.06(31)$ & $0.04(1550)$ & $0.04(163)$ & $0.02(14)$ & $0.04(1819)$ \\
\hline \multicolumn{8}{|l|}{ Calendar year of cohort enrolment } \\
\hline Before 2000 & 0.15 & 0.09 & 0.06 & 0.22 & 0.07 & 0.07 & 0.20 \\
\hline 2000-2004 & 0.44 & 0.39 & 0.38 & 0.38 & 0.39 & 0.28 & 0.39 \\
\hline 2005-2009 & 0.41 & 0.51 & 0.56 & 0.39 & 0.54 & 0.65 & 0.42 \\
\hline $\begin{array}{l}\text { No. of CD4 cell count } \\
\text { measurements, median }\end{array}$ & 6 & 6 & 5 & 6 & 5 & 5 & 6 \\
\hline CD4, cells/ $\mu \mathrm{L}$, median & 420 & 450 & 440 & 470 & 400 & 420 & 460 \\
\hline CD4\%, median & $24(73)$ & $27(32)$ & $24(42)$ & $26(901)$ & $23(143)$ & $23(17)$ & 26 (1208) \\
\hline CD8, cells/ $\mu \mathrm{L}$, median & $910(82)$ & 900 (39) & $860(50)$ & $930(1125)$ & $900(177)$ & $850(18)$ & $920(1491)$ \\
\hline HIV RNA, log copies/mL, median & $4.1(13)$ & $4.2(1)$ & $4.1(2)$ & $4.4(44)$ & $4.0(9)$ & 4.1 & $4.3(69)$ \\
\hline Follow-up time, yr, median & 1.59 & 1.78 & 1.40 & 1.75 & 1.39 & 1.51 & 1.69 \\
\hline
\end{tabular}




\section{OPEN}

Table 3: Baseline characteristics of the study population by patient ethnicity: median or proportion of column total; numbers in parentheses represent missing observations

\begin{tabular}{|c|c|c|c|c|}
\hline Variable & $\begin{array}{c}\text { African ancestry } \\
\quad n=1303\end{array}$ & $\begin{array}{c}\text { Other ethnicity } \\
n=7373\end{array}$ & $\begin{array}{c}\text { Unknown ethnicity } \\
\qquad n=1096\end{array}$ & $\begin{array}{c}\text { Total } \\
n=9772\end{array}$ \\
\hline Age, yr, median & 33 & 35 & 36 & 35 \\
\hline Sex, female & 0.55 & 0.12 & 0.19 & 0.19 \\
\hline \multicolumn{5}{|l|}{ Likely mode of transmission } \\
\hline Heterosexual & 0.68 & 0.14 & 0.13 & 0.21 \\
\hline Men who have sex with men & 0.15 & 0.68 & 0.35 & 0.57 \\
\hline Injection drug use & 0.01 & 0.11 & 0.17 & 0.11 \\
\hline Other or unknown & 0.15 & 0.07 & 0.36 & 0.11 \\
\hline Hepatitis C co-infection & $0.03(201)$ & $0.18(810)$ & $0.19(353)$ & $0.16(1364)$ \\
\hline Hepatitis B co-infection & $0.06(192)$ & $0.04(1078)$ & $0.02(549)$ & $0.04(1819)$ \\
\hline \multicolumn{5}{|l|}{ Calendar year of cohort enrolment } \\
\hline Before 2000 & 0.09 & 0.21 & 0.22 & 0.20 \\
\hline 2000-2004 & 0.40 & 0.38 & 0.43 & 0.39 \\
\hline 2005-2009 & 0.51 & 0.41 & 0.35 & 0.42 \\
\hline No. of CD4 cell count measurements, median & 5 & 6 & 5 & 6 \\
\hline CD4 cell count, cells/ $\mu \mathrm{L}$, median & 400 & 470 & 470 & 460 \\
\hline CD4\%, median & $23(225)$ & $26(932)$ & $26(51)$ & $26(1208)$ \\
\hline CD8 cell count, cells $/ \mu \mathrm{L}$, median & $880(275)$ & $940(1163)$ & $900(53)$ & $920(1491)$ \\
\hline HIV RNA, log copies/mL, median & $4.0(10)$ & $4.4(56)$ & $4.5(3)$ & $4.3(69)$ \\
\hline Follow-up time, yr, median & 1.42 & 1.76 & 1.56 & 1.69 \\
\hline
\end{tabular}

Table 4: Change over time in square root CD4 cell count by HIV-1 subtype and patient ethnicity

\begin{tabular}{|c|c|c|c|c|c|}
\hline \multicolumn{6}{|c|}{ Slope estimate $(95 \% \mathrm{Cl})$} \\
\hline & \multicolumn{4}{|c|}{ Selected CD4 cell counts ${ }^{*}$} & $\begin{array}{l}\text { Unselected CD4 cell } \\
\text { counts† }\end{array}$ \\
\hline & \multicolumn{2}{|c|}{ All patients included in analysis } & $\begin{array}{l}\text { Only patients of } \\
\text { African ancestry } \\
\text { included in analysis }\end{array}$ & $\begin{array}{l}\text { Only patients of other } \\
\text { ethnicity included in } \\
\text { analysis }\end{array}$ & $\begin{array}{l}\text { All patients included in } \\
\text { analysis }\end{array}$ \\
\hline & \multicolumn{5}{|c|}{ Mixed modelł } \\
\hline & With ethnicity & Without ethnicity & & & With ethnicity \\
\hline \multicolumn{6}{|c|}{ Change per year: patients of other ethnicity with viral subtype B } \\
\hline & $-1.23(-1.27$ to -1.19$)$ & $-1.21(-1.25$ to -1.17$)$ & $-0.88(-1.03$ to -0.73$)$ & $-1.23(-1.27$ to -1.19$)$ & $-1.35(-1.40$ to -1.31$)$ \\
\hline \multicolumn{6}{|c|}{ Difference in change per year compared with the change in patients of other ethnicity with viral subtype $B$} \\
\hline \multicolumn{6}{|l|}{ Viral subtype } \\
\hline A & $0.06(-0.13$ to 0.25$)$ & $0.21 \quad(0.02$ to 0.39$)$ & $0.22(-0.04$ to 0.49$)$ & $0.03(-0.22$ to 0.28$)$ & $0.30 \quad(0.10$ to 0.49$)$ \\
\hline $\mathrm{AE}$ & $-0.03(-0.26$ to 0.21$)$ & $-0.05(-0.28$ to 0.19$)$ & $-3.2 \quad(-8.6$ to 2.2$) \S$ & $-0.04(-0.28$ to 0.20$)$ & $0.03(-0.23$ to 0.28$)$ \\
\hline AG & $0.17(-0.04$ to 0.39$)$ & $0.34 \quad(0.13$ to 0.55$)$ & $0.26(-0.02$ to 0.54$)$ & $0.24(-0.08$ to 0.55$)$ & $0.23 \quad(0.00$ to 0.46$)$ \\
\hline C & $0.11(-0.04$ to 0.27$)$ & 0.32 (0.19 to 0.46$)$ & $0.32 \quad(0.12$ to 0.52$)$ & $-0.02(-0.24$ to 0.20$)$ & $0.31 \quad(0.15$ to 0.47$)$ \\
\hline G & 0.02 ( -0.32 to 0.36$)$ & $0.19(-0.14$ to 0.52$)$ & $0.46 \quad(0.06$ to 0.86$)$ & $-0.42(-0.92$ to 0.09$)$ & $0.00(-0.37$ to 0.36$)$ \\
\hline African ancestry & $0.37 \quad(0.25$ to 0.50$)$ & & & & $0.44 \quad(0.31$ to 0.57$)$ \\
\hline \multicolumn{6}{|c|}{$\begin{array}{l}\text { Note: } \mathrm{Cl} \text { = confidence interval. } \\
\text { *Patients aged } 16 \text { years or older after January } 1998 \text { with CD4 cell counts likely to be within the stable phase of chronic untreated HIV infection. } \\
\text { †All CD4 cell counts for patients aged } 16 \text { years and older after January } 1998 \text {. } \\
\text { †Mixed model with a random intercept and random slope for each patient. All cohorts except Aquitaine. With intercepts for cohort and with both intercepts and slopes for } \\
\text { age, sex, ethnicity, initial HIV RNA, and injection drug use as the likely mode of transmission. } \\
\text { §Few patients of African ancestry had viral subtype AE; therefore, this point estimate is unreliable. }\end{array}$} \\
\hline
\end{tabular}




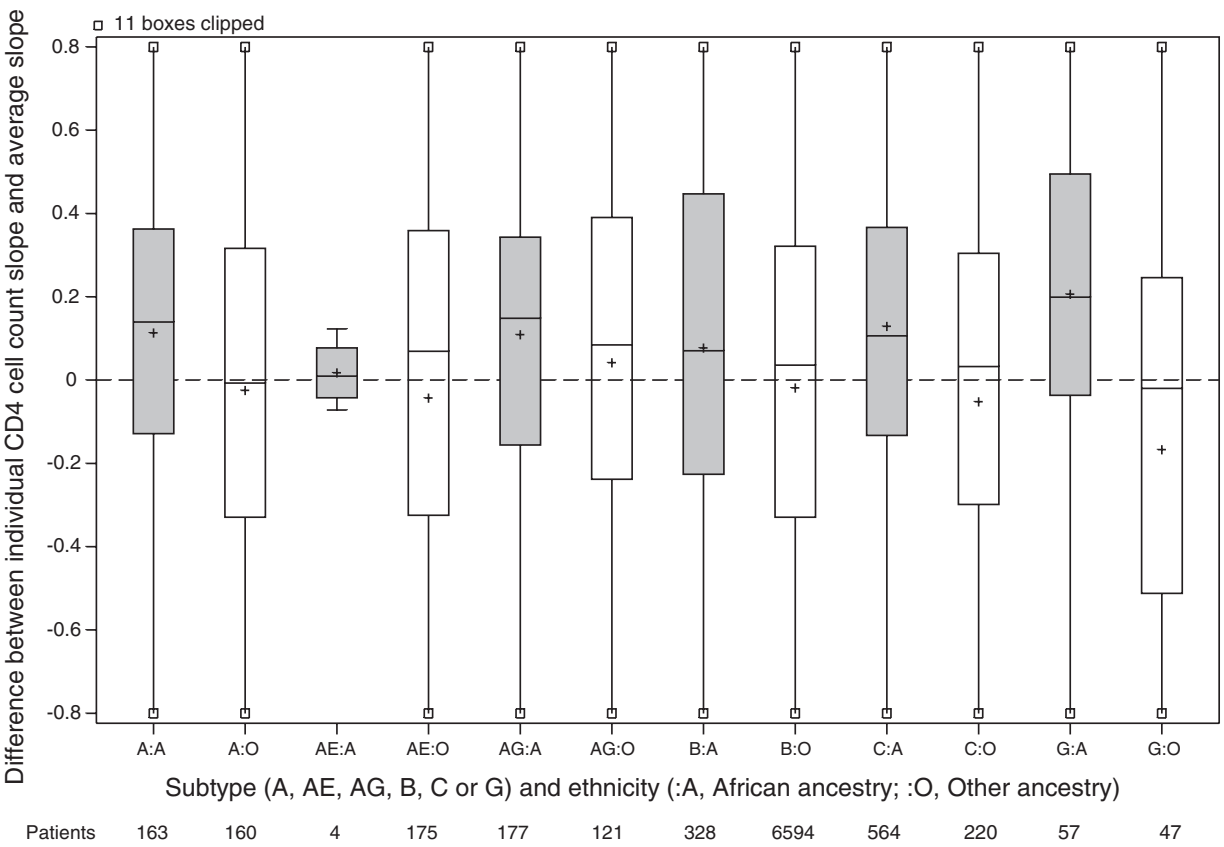

Figure 2: Estimated CD4 cell count slope decline for each patient. Random effects representing each patient's CD4 cell count decline (compared with the average) estimated in a mixed model without ethnicity or subtype slope parameters but adjusted for covariates. All cohorts are included in the model except Aquitaine. Grey shading = patients of African ancestry, white shading $=$ patients of other ethnicities, + = mean.

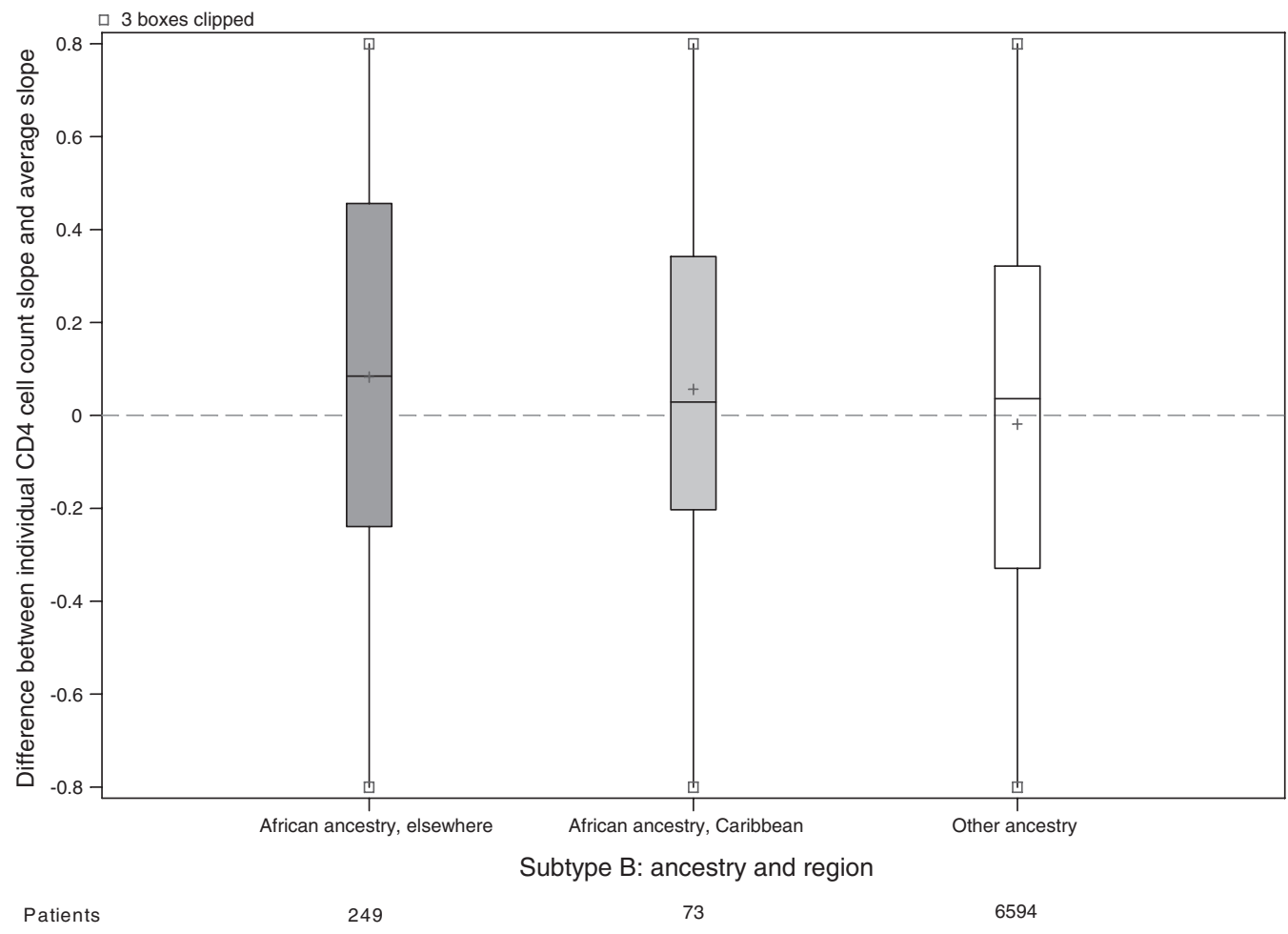

Figure 3: Estimated decline in CD4 cell count slope for each patient with viral subtype B. Random effects represnting each patient's CD4 cell count decline (compared with the average) estimated in a mixed model without ethnicity or subtype slope parameters but adjusted for covariates. All cohorts are represented in the model except Aquitaine; however, the only patients shown in this plot have HIV subtype B. Grey shading = patients of African ancestry, white shading = patients of other ethnicities, $+=$ mean . 
sufficient data to estimate this interaction in a single model. Our data suggest that there is little variation between viral subtypes in both initial CD4 cell count and its decline in patients of other ethnicities (Table 5). Model parameters imply that it would take a reference patient of African ancestry with viral subtype C 1.2 years to reach a threshold of 350 cells/ $\mu \mathrm{L}$ and 9.3 years to reach a threshold of 200 cells $/ \mu \mathrm{L}$, whereas a reference patient of another ethnicity with viral subtype B would take 2.5 years to reach a threshold of 350 cells $/ \mu \mathrm{L}$ and 6.2 years to reach a threshold of 200 cells $/ \mu \mathrm{L}$ (footnote to Table 5). Figure 4 shows the estimated average CD4 cell count decline over 5 years in patients of African ancestry with viral subtype $\mathrm{C}$ and in patients of other ethnicities with viral subtype $\mathrm{B}$.

Estimates of CD4 cell count decline did not change appreciably in a joint model (Table 6). In the longitudinal component of the joint model, lower initial CD4 cell count and more rapid decline were associated with older age, female sex, injection drug use as the likely mode of transmission and higher initial HIV RNA. In the time-to-event component of the joint model, earlier antiretroviral therapy was associated with older age, female sex, higher initial HIV RNA, more recent calendar time and African ancestry. There was no evidence from this model that viral subtype and ethnicity slope estimates were biased by informative censoring because of early antiretroviral therapy.

In other sensitivity analyses, we added a time-dependent CD8 cell count (not available from the EuroSIDA cohort); we replaced injection drug use as the likely mode of transmission with covariates for hepatitis $\mathrm{C}$ and chronic hepatitis $\mathrm{B}$ virus co-infection (not available from the HAART Observational Medical Evaluation and Research Study (HOMER) cohort). Subtype and ethnicity slope estimates were not materially different in these analyses.

We report clinical outcomes using unselected CD4 cell count series (Table 7) because selected series were often censored by irregular measurement. There were no appreciable differences between viral subtypes and ethnicities in either the proportion of patients starting antiretroviral therapy or the median CD4 cell count when starting. However, the median time taken to start antiretroviral therapy was shorter among patients of African ancestry (0.51 v. $1.27 \mathrm{yr}$; Table 7), consistent with their lower initial CD4 cell count (400 v. 470 cells/ $\mu \mathrm{L}$; Table 3). Within each viral subtype, no more than $14 \%$ of patients had an AIDS-defining illness, and $1 \%$ of patients died during a median follow-up at around 2 years. There was no obvious relation between the number of these clinical events and the rate of CD4 cell count decline by either viral subtype or ethnicity.

\begin{tabular}{|c|c|c|}
\hline \multirow[b]{2}{*}{ HIV-1 infection subtype } & \multicolumn{2}{|c|}{ CD4 cell count, cells/ $\mu \mathrm{L}$} \\
\hline & Initial $^{\star}(95 \% \mathrm{Cl})$ & Change per year† $(95 \% \mathrm{Cl})$ \\
\hline \multicolumn{3}{|c|}{ Mixed model for patients of African ancestry } \\
\hline B & 477 (447 to 507$)$ & $-35(-42$ to -28$)$ \\
\hline A & $392(353$ to 430$)$ & $-23(-35$ to -12$)$ \\
\hline $\mathrm{AE}$ & 348 (173 to 523$) \ddagger$ & $-146(-386$ to 95$) \ddagger$ \\
\hline AG & 398 (361 to 435$)$ & $-23(-35$ to -11$)$ \\
\hline $\mathrm{C}$ & 395 (366 to 425$)$ & $-19(-27$ to -11$)$ \\
\hline $\mathrm{G}$ & 413 (361 to 465$)$ & $-13(-31$ to 5$)$ \\
\hline \multicolumn{3}{|c|}{ Mixed model for patients of other ethnicities } \\
\hline $\mathrm{B}$ & 492 (469 to 516$)$ & $-49(-51$ to -47$)$ \\
\hline A & 480 (441 to 519$)$ & $-49(-59$ to -38$)$ \\
\hline $\mathrm{AE}$ & 484 (447 to 522$)$ & $-50 \quad(-60$ to -40$)$ \\
\hline$A G$ & 505 (462 to 548$)$ & $-41 \quad(-54$ to -27$)$ \\
\hline $\mathrm{C}$ & 489 (454 to 524$)$ & $-52(-62$ to -43$)$ \\
\hline $\mathrm{G}$ & 468 (406 to 530$)$ & $-60 \quad(-82$ to -38$)$ \\
\hline \multicolumn{3}{|c|}{ 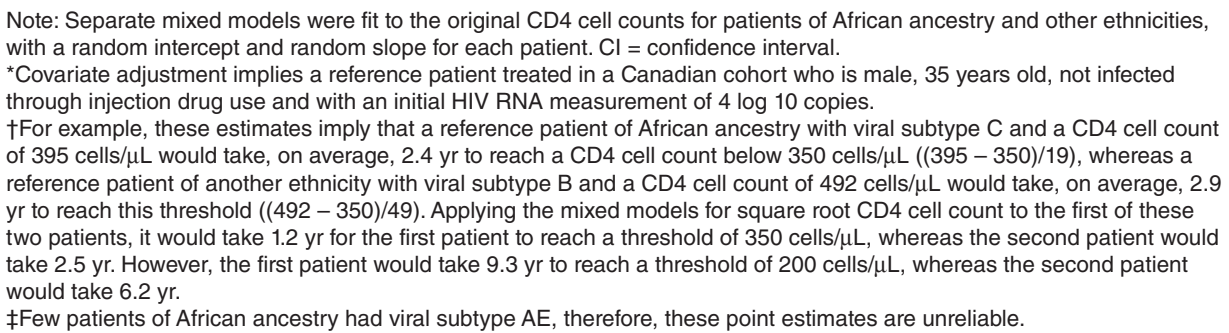 } \\
\hline
\end{tabular}




\section{Interpretation}

\section{Main findings}

The study explores the effects of both viral subtype and ethnicity on CD4 cell count decline in untreated patients during the chronic phase of HIV infection. ${ }^{14} \mathrm{We}$ focused on the chronic phase because it is the longest period of untreated HIV infection. We were able to compare all of the predominant subtypes directly with one another. Indeed, the proportions of viral subtypes studied (other than B) mirrored their proportions in the worldwide HIV epidemic. ${ }^{3}$ We found that ethnicity is the major determinant of $\mathrm{CD} 4$ cell count decline; viral subtype differences may exist but were small compared with the effect of ethnicity and were most apparent in patients of African ancestry. Patients of African ancestry had slower rates of CD4 cell count decline overall. Although the viral subtypes other than B, with the exception of CRF01_AE, appeared to be associated with slower CD4 cell count decline in models that did not include a slope for African ancestry, these effects were greatly attenuated once this slope was included. Furthermore, in plots of CD4 cell count decline by viral subtype and ethnicity, patients of African ancestry had slower rates of CD4 cell count decline within each viral subtype, including within viral subtype B. Together these results suggest that differences between viral subtypes are small compared with the broader effect of ethnicity on immunologic progression. Failure to account for ethnicity in the evaluation of viral subtype effects could potentially lead to erroneous conclusions.
Strong associations between viral subtype and ethnicity exist. Only $5 \%$ of patients with viral subtype B and $3 \%$ of those with CRF01_AE infection were of African ancestry compared with more than $50 \%$ of those infected with other subtypes. We therefore examined the effects of viral subtype in each ethnic group separately. Among patients of other ethnicities, there was little evidence for an effect of viral subtype on immunologic progression. In contrast, patients of African ancestry with viral subtype C (and possibly A, CRF02_AG and G) may have slower rates of decline in cell count compared with patients of African ancestry with viral subtype $B$. This suggests viral subtype may have different effects depending on ethnicity.

\section{Explanation and comparisons with other studies}

Indeed, biological differences between viral subtypes do exist that might affect immunologic progression. For example, coreceptor use varies among viral subtypes, with $\mathrm{A}$ and $\mathrm{C}$ predominantly using the coreceptor (R5) that is associated with slower disease progression, and viral subtype $\mathrm{C}$ has lower replicative fitness when compared with other viral subtypes in vitro. ${ }^{13}$ Observational studies also support differences in disease progression among patients of African ancestry with infections of differing viral subtype. For example, faster immunologic progression has been reported in patients from Uganda and Kenya with viral subtype D compared with viral subtype A. ${ }^{28-30}$ Co-evolution of HIV-1 subtypes and African populations may reduce the virulence of more dominant viral subtypes, such as subtype C, possibly leading to an interaction
A

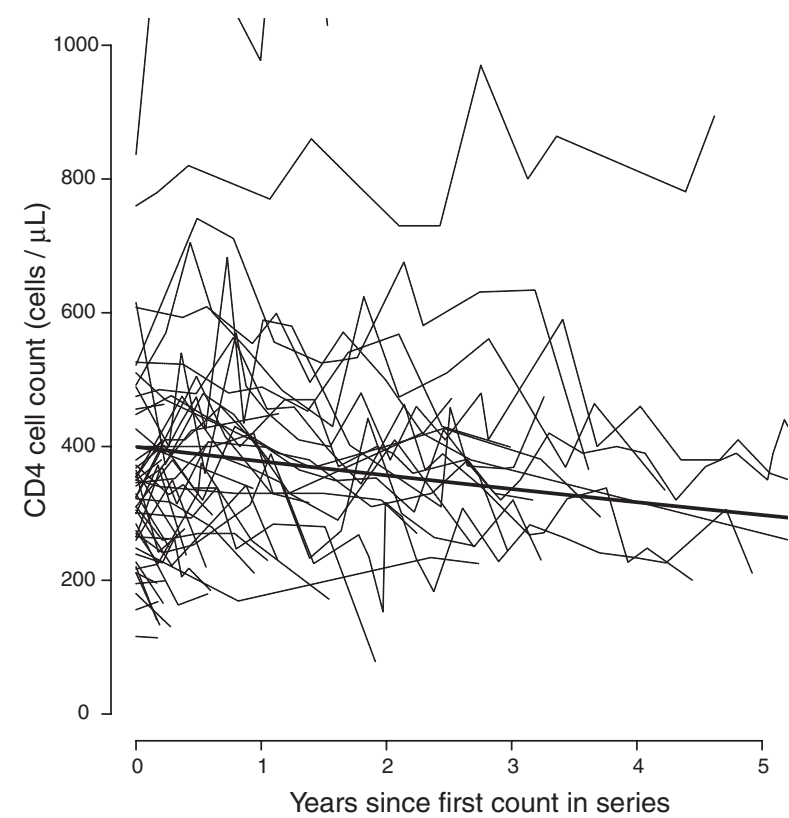

B

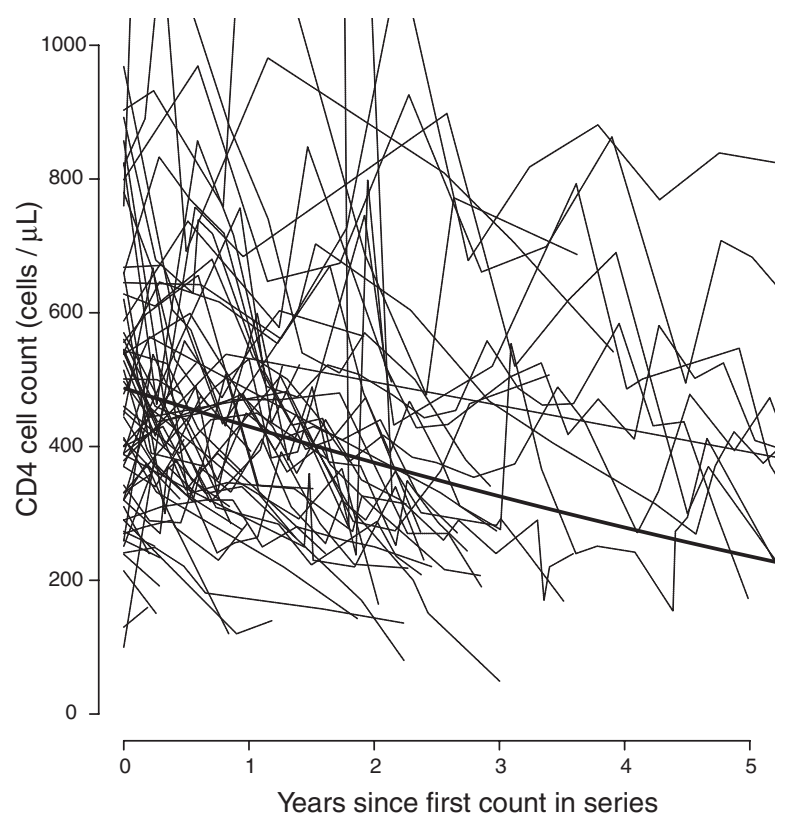

Figure 4: Estimated average CD4 cell count over 5 years. The average CD4 cell count estimated (A) in patients of African ancestry with viral subtype $C$ and $(B)$ in patients of other ethnicities with viral subtype $B$. Estimates were made using separate mixed models: one for patients of African ancestry and one for patients of other ethnicities and represent CD4 cell counts in a male patient with infection not transmitted by injection drug use and with age and initial HIV RNA set at the median for that ethnicity and subtype. CD4 cell count trajectories are shown for a $10 \%$ sample of patients of African ancestry with viral subtype $C$ and for a $1 \%$ sample of patients of other ethnicities with viral subtype B. 


\section{OPEN}

Research

between viral subtype and ethnicity. ${ }^{2}$ In the absence of antiretroviral therapy, which is still the reality for most people infected with HIV in Africa, our results suggest that a patient of African ancestry with a non-subtype-B infection could take considerably longer to reach a CD4 cell count of 200 cells/ $\mu \mathrm{L}$
(9.3 v. 6.2 yr; Table 5), the level at which the risk of AIDS increases, thus prolonging the asymptomatic period and increasing the opportunity for HIV transmission. ${ }^{31,32}$ Because of the small number of clinical events and deaths, we were not able to determine if differences in CD4 cell count decline

\begin{tabular}{|c|c|c|}
\hline Variable & $\begin{array}{l}\text { Separate model estimate } \\
\qquad(95 \% \mathrm{Cl})\end{array}$ & $\begin{array}{l}\text { Joint model estimate } \\
\qquad(95 \% \mathrm{Cl})\end{array}$ \\
\hline \multicolumn{3}{|l|}{ Mixed model } \\
\hline \multicolumn{3}{|l|}{ Starting CD4 cell count, cells/ $\mu \mathrm{L}^{*} \dagger$} \\
\hline Reference patient ${ }^{*}$ & $21.88(21.47$ to 22.29$)$ & 22.02 (21.60 to 22.43$)$ \\
\hline Female & $-0.20(-0.49$ to 0.08$)$ & $-0.24(-0.51$ to 0.04$)$ \\
\hline Injection drug use $†$ & $-1.16(-1.50$ to -0.82$)$ & $-1.12(-1.49$ to -0.78$)$ \\
\hline Age (per $10 \mathrm{yr}$ ) & $-0.19(-0.29$ to -0.08$)$ & $-0.18(-0.29$ to -0.07$)$ \\
\hline $\log _{10}$ HIV RNA (per log copy) & $-1.51(-1.62$ to -1.40$)$ & $-1.51(-1.62$ to -1.40$)$ \\
\hline \multicolumn{3}{|l|}{ Cohort (reference ROC) } \\
\hline EuroSIDA & $1.55 \quad(0.88$ to 2.21$)$ & 1.36 (0.69 to 2.03$)$ \\
\hline HOMER & $-0.77(-1.32$ to -0.23$)$ & $-0.98(-1.53$ to -0.43$)$ \\
\hline SHCS & $1.10 \quad(0.66$ to 1.55$)$ & $0.95(0.50$ to 1.39$)$ \\
\hline UK CHIC & $0.82 \quad(0.41$ to 1.24$)$ & $0.71 \quad(0.29$ to 1.13$)$ \\
\hline \multicolumn{3}{|c|}{ Viral subtype (reference subtype B) } \\
\hline A & $-0.69(-1.20$ to -0.18$)$ & $-0.63(-1.12$ to -0.14$)$ \\
\hline $\mathrm{AE}$ & $-0.24(-0.88$ to 0.40$)$ & $-0.20(-0.81$ to 0.40$)$ \\
\hline$A G$ & $-0.43(-0.98$ to 0.11$)$ & $-0.39(-0.91$ to 0.13$)$ \\
\hline C & $-0.78(-1.18$ to -0.38$)$ & $-0.71(-1.10$ to -0.33$)$ \\
\hline G§ & $-0.58(-1.43$ to 0.27$)$ & - \\
\hline African ancestry & $-1.57(-1.91$ to -1.23$)$ & $-1.60(-1.94$ to -1.25$)$ \\
\hline \multicolumn{3}{|c|}{ Rate of CD4 cell count decline, (cells $/ \mu \mathrm{L}) / \mathrm{yr}^{*} \dagger$} \\
\hline Reference patient ${ }^{*}$ & $-1.23(-1.27$ to -1.19$)$ & $-1.29(-1.34$ to -1.25$)$ \\
\hline Female & $-0.08(-0.19$ to 0.02$)$ & $-0.13(-0.23$ to -0.02$)$ \\
\hline Injection drug use $†$ & $-0.10(-0.22$ to 0.02$)$ & $-0.16(-0.28$ to -0.04$)$ \\
\hline Age (per $10 \mathrm{yr}$ ) & $-0.09(-0.13$ to -0.05$)$ & $-0.11(-0.15$ to -0.07$)$ \\
\hline $\log _{10}$ HIV RNA (per log copy) & $-0.28(-0.32$ to -0.23$)$ & $-0.30(-0.34$ to -0.26$)$ \\
\hline \multicolumn{3}{|l|}{ Subtype (reference subtype B) } \\
\hline A & $0.06(-0.13$ to 0.25$)$ & $0.08(-0.10$ to 0.26$)$ \\
\hline $\mathrm{AE}$ & $-0.03(-0.26$ to 0.21$)$ & $-0.01(-0.24$ to 0.21$)$ \\
\hline$A G$ & $0.17(-0.04$ to 0.39$)$ & $0.17(-0.04$ to 0.38$)$ \\
\hline $\mathrm{C}$ & $0.11(-0.04$ to 0.27$)$ & $0.14(0.00$ to 0.29$)$ \\
\hline G§ & $0.02(-0.32$ to 0.36$)$ & - \\
\hline African ancestry & $0.37 \quad(0.25$ to 0.50$)$ & 0.29 (0.17 to 0.42$)$ \\
\hline \multicolumn{3}{|l|}{ AFT model } \\
\hline Reference patient* & $1.60 \quad(1.44$ to 1.76$)$ & 1.81 (1.62 to 2.00$)$ \\
\hline Female & $-0.21(-0.31$ to -0.11$)$ & $-0.26(-0.38$ to -0.15$)$ \\
\hline Injection drug use $†$ & $0.04(-0.08$ to 0.17$)$ & $-0.05(-0.19$ to 0.10$)$ \\
\hline Age (per $10 \mathrm{yr}$ ) & $-0.07(-0.11$ to -0.03$)$ & $-0.11(-0.15$ to -0.06$)$ \\
\hline $\log _{10}$ HIV RNA & $-0.37(-0.41$ to -0.32$)$ & $-0.54(-0.60$ to -0.48$)$ \\
\hline \multicolumn{3}{|l|}{ Cohort (reference ROC) $\ddagger$} \\
\hline EuroSIDA & $0.01(-0.24$ to 0.26$)$ & $0.05(-0.23$ to 0.33$)$ \\
\hline HOMER & $-0.14(-0.35$ to 0.07$)$ & $-0.10(-0.34$ to 0.14$)$ \\
\hline SHCS & $-0.10(-0.28$ to 0.07$)$ & $-0.02(-0.21$ to 0.18$)$ \\
\hline UK CHIC & $0.54 \quad(0.37$ to 0.71$)$ & $0.62(0.43$ to 0.81$)$ \\
\hline Calendar time (per $10 \mathrm{yr}$ ) & $-0.66(-0.78$ to -0.53$)$ & $-0.34(-0.47$ to -0.21$)$ \\
\hline African ancestry & $-0.10(-0.21$ to 0.02$)$ & $-0.33(-0.47$ to -0.19$)$ \\
\hline CD4 cell count (square root) & $0.12 \quad(0.11$ to 0.13$)$ & $0.02(0.00$ to 0.04$)$ \\
\hline \multicolumn{3}{|c|}{$\begin{array}{l}\text { Note: EuroSIDA is a prospective observational cohort study in } 33 \text { European countries and Israel and Argentina. HOMER = HAART } \\
\text { Observational Medical Evaluation and Research study, SHCS = Swiss HIV Cohort Study, UK CHIC = UK Collaborative HIV Cohort study. } \\
{ }^{*} \text { Covariate adjustment implies a reference patient treated in a Canadian cohort, male, } 35 \text { years old, not infected through injection drug use, } \\
\text { with a starting HIV RNA of } 4 \text { log } 10 \text { copies, infected with viral subtype B and not of African ancestry. } \\
\text { †The most likely mode of HIV transmission. } \\
\text { †Rest of Canada (ROC; Calgary, Hamilton, Montréal, Ottawa and Toronto cohorts). } \\
\text { §A joint model including patients with viral subtype G gave implausible parameter estimates. }\end{array}$} \\
\hline
\end{tabular}


would translate into different risks of AIDS or mortality for people of different ethnicities.

Several previous studies in both incident ${ }^{33,34}$ and prevalent ${ }^{4,16,17}$ cohorts have shown that African ancestry is associated with slower rates of CD4 cell count decline, but with one exception, ${ }^{33}$ have not included viral subtype and ethnicity in the same analysis. ${ }^{14}$ Yet, it remains unclear how ethnicity could affect the underlying pathogenesis of HIV infection. ${ }^{35}$ Those patients classified as being of African ancestry in our study came from a large number of African and Caribbean countries, suggesting no single host characteristic is likely to be responsible for differences in disease progression. Differential patterns of migration and racial admixture in Caribbean populations should reduce differences owing to ethnicity; this was shown in an analysis where patients from Haiti and patients from Canada (both sets of patients with subtype B infection) had similar rates of CD4 cell count decline, which were faster than the rate observed among recent immigrants from Africa. ${ }^{36}$ In our study, patients with subtype $\mathrm{B}$ infection from the Caribbean appeared to have rates of $\mathrm{CD} 4$ cell count decline intermediate to rates of $\mathrm{CD} 4$ cell count decline in patients with subtype B infection from Africa and other countries.

Individuals of similar ethnicity do share genetic characteristics that have been associated with HIV disease progression. Examples include protective human leukocyte antigen haplotypes, chemokine and chemokine receptor polymorphisms, and mutational variants in genes involved in immune regulation. ${ }^{37,38}$ It is also possible that ethnicity simply serves as a marker for socioeconomic, cultural and environmental factors that may influence immunologic progression. ${ }^{31}$ In our study, patients of African ancestry were more likely to be female and of child-bearing age, have lower initial CD4 cell counts and to have started antiretroviral therapy sooner. However, our joint model showed no evidence of informative censoring owing to early antiretroviral therapy. The healthy migrant effect is an alternate explanation for differences between patients of African ancestry and other ethnicities receiving health care in developed countries, ${ }^{39}$ but this does not explain reported differences in patients from Africa or the United States. ${ }^{15,16,34,40}$ In our study, adjustment for time-updated CD8 cell count, a crude marker of immune activation, or for hepatitis co-infection did not affect estimates of differences in CD4 cell count decline. A healthy migrant effect implies that ethnic differences should be attenuated after adjusting for comorbidities.

\section{Limitations}

Our classification of ethnicity was rudimentary based on different classifications in each cohort or, for 2 cohorts, derived from country of origin, and ethnicity was unknown for $11 \%$ of patients. We also had insufficient patients of Asian ancestry to pursue a separate study. Patients included in this study were undergoing treatment in countries with publicly funded health care, minimizing the potential effects of health care access and quality on immunologic progression, but our results might not be generalizable to resource-limited settings. We did not have enough patients with other viral subtypes linked to faster CD4 cell count decline, such as viral subtype D..$^{28-30,40}$ In addition, limited numbers of both viral subtypes G and CRF01_AE in patients of African ancestry means our estimates for these subtypes were imprecise. We were not able to adjust for sociodemographic factors beyond age and sex. Multiple-host, socioeconomic and environmental factors are shared among individuals of common ancestry, which may impact CD4 cell count decline. Single-cohort studies are needed to see if ethnic differences within the same viral subtype are attenuated with adjustment for specific socioeconomic and environmental factors.

\section{Table 7: Clinical outcomes in unselected CD4 cell counts (median or proportion) by viral subtype and patient ethnicity}

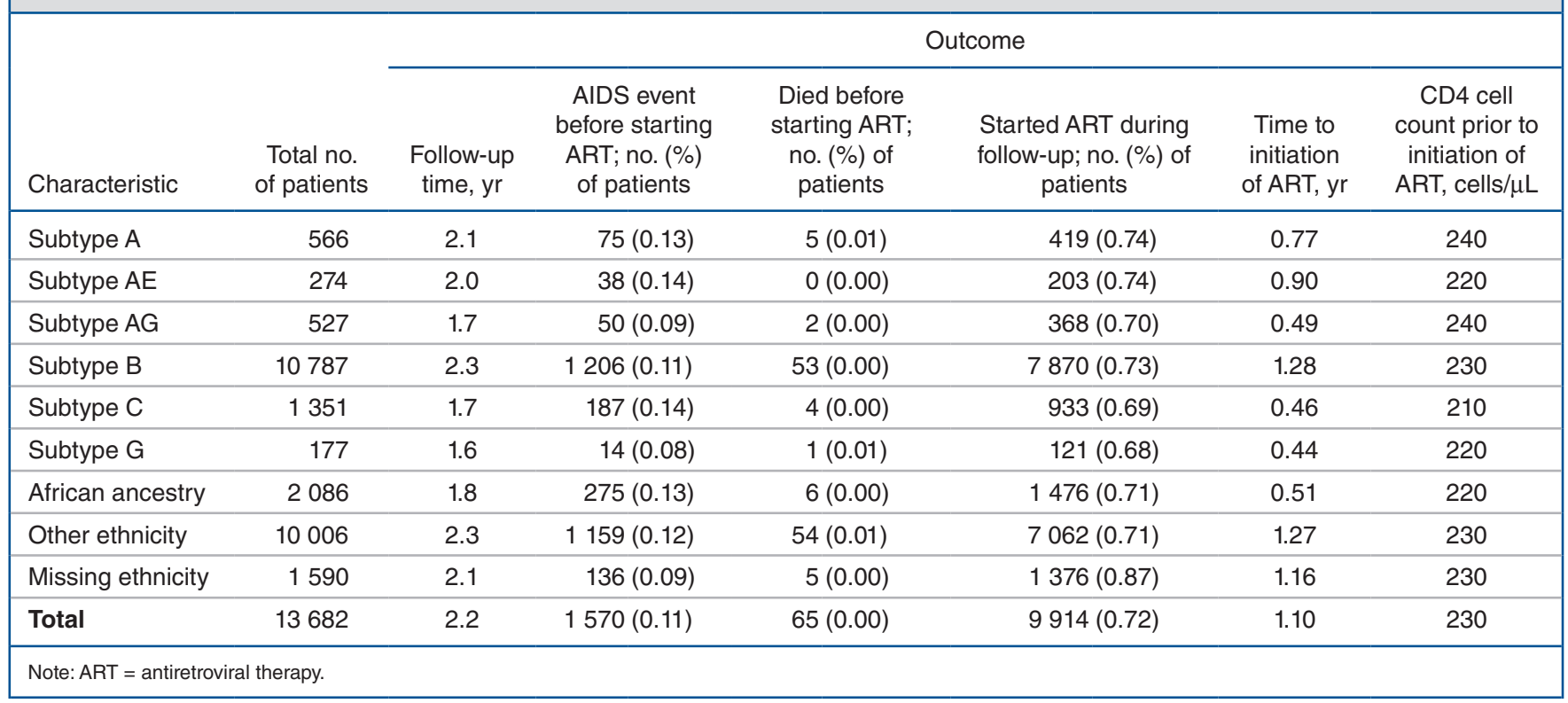




\section{Conclusions and implications for practice and future research}

This large collaborative analysis with a broad representation of the most common HIV-1 subtypes worldwide suggests that ethnicity is more prognostic of immunologic progression than viral subtype during untreated chronic HIV infection. Although there is some evidence of differences in CD4 cell count decline between viral subtypes, particularly in patients of African ancestry, research to uncover the underlying biologic or sociologic reasons for slower immunologic progression among patients of African ancestry is warranted. Further study of subtype-specific effects on immunologic progression will require comparisons of different subtypes in ethnically homogeneous populations.

\section{References}

1. Taylor BS, Sobieszczyk ME, McCutchan FE, et al. The challenge of HIV-1 subtype diversity [published erratum in N Engl f Med 2008;359:1965-6, N Engl 7 Med 2008;359:1972]. N Engl 7 Med 2008;358:1590-602.

2. Tebit DM, Arts EJ. Tracking a century of global expansion and evolution of HIV to drive understanding and to combat disease. Lancet Infect Dis 2011; 11:45-56.

3. Hemelaar J, Gouws E, Ghys PD, et al. Global trends in molecular epidemiology of HIV-1 during 2000-2007. AIDS 2011;25:679-89.

4. Del Amo J, Broring G, Hamers FF, et al. Monitoring HIV/AIDS in Europe's migrant communities and ethnic minorities. AIDS 2004;18:1867-73.

5. HIV/AIDS epi updates, Fuly 2010. Ottawa: Public Health Agency of Canada; 2010. Available: www.phac-aspc.gc.ca/aids-sida/publication/epi/2010/pdf/EN Intro_Web.pdf (accessed 2014 Sept. 25).

6. Chaix ML, Seng R, Frange P, et al. Increasing HIV-1 non-B subtype primary infections in patients in France and effect of HIV subtypes on virological and immunological responses to combined antiretroviral therapy. Clin Infect Dis 2013;56:880-7.

7. HIV-1 strain and transmitted drug resistance in Canada: surveillance report to December 31, 2008. Ottawa: Public Health Agency of Canada; 2012. Available: http://publications.gc.ca/collections/collection_2013/aspc-phac/HP37-13-2008 -eng.pdf (accessed 2014 Sept. 25).

8. Rice BD, Elford J, Yin Z, et al. A new method to assign country of HIV infection among heterosexuals born abroad and diagnosed with HIV. AIDS 2012;26:1961-6.

9. Hu DJ, Vanichseni S, Mastro TD, et al. Viral load differences in early infection with two HIV-1 subtypes. AIDS 2001;15:683-91.

10. Chohan B, Lang D, Sagar M, et al. Selection for human immunodeficiency virus type 1 envelope glycosylation variants with shorter V1-V2 loop sequences occurs during transmission of certain genetic subtypes and may impact viral RNA levels. F Virol 2005;79:6528-31.

11. Ndung'u T, Sepako E, McLane MF, et al. HIV-1 subtype C in vitro growth and coreceptor utilization. Virology 2006;347:247-60.

12. Huang W, Eshleman SH, Toma J, et al. Coreceptor tropism in human immunodeficiency virus type 1 subtype D: high prevalence of CXCR4 tropism and heterogeneous composition of viral populations. 7 Virol 2007;81:7885-93.

13. Abraha A, Nankya IL, Gibson R, et al. CCR5- and CXCR4-tropic subtype C human immunodeficiency virus type 1 isolates have a lower level of pathogenic fitness than other dominant group $M$ subtypes: implications for the epidemic. 7 Virol 2009;83:5592-605.

14. Young J, Klein MB. Virus subtype, ethnicity and CD4 decline in untreated HIV infection. Future Virol 2014;9:337-40.

15. Anastos K, Gange SJ, Lau B, et al. Association of race and gender with HIV-1 RNA levels and immunologic progression. 7 Acquir Immune Defic Syndr 2000;24:218-26.

16. May M, Wood R, Myer L, et al. CD4(+) T cell count decreases by ethnicity among untreated patients with HIV infection in South Africa and Switzerland. F Infect Dis 2009;200:1729-35.

17. Müller V, von $W_{y l} \mathrm{~V}$, Yerly S, et al. African descent is associated with slower CD4 cell count decline in treatment-naive patients of the Swiss HIV Cohort Study. AIDS 2009;23:1269-76.

18. Palmer AK, Klein MB, Raboud J, et al. Cohort profile: the Canadian Observational Cohort collaboration. Int 7 Epidemiol 2011;40:25-32.

19. May MT, Ingle SM, Costagliola D, et al. Cohort profile: Antiretroviral Therapy Cohort Collaboration (ART-CC). Int 7 Epidemiol 2014;43:691-702.

20. Dabis F. ANRS CO3 Aquitaine: Cohortes dans l'infection par le VIH et hépatites, co-Infection menées sous l'égide de l'ANRS (Janvier 2013). Available: www.anrs.fr/content/download/777/5213/file/Anrs_CO3_Aquitaine.pdf (accessed 2014 Sept. 25)

21. Paulsen MA, Mocroft A, Ellefson M, eds. et al. EuroSIDA a multicentre study,
1994-2009. Copenhagen (Denmark): Copenhagen HIV Programme; 2009. Available: www.cphiv.dk/Ongoing-Studies/EuroSIDA/Publications/EuroSIDA -a-multicenter-study-1994-2009 (accessed 2014 Sept. 25).

22. Schoeni-Affolter F, Ledergerber B, Rickenbach M, et al. Cohort profile: the Swiss HIV Cohort study. Int 7 Epidemiol 2010;39:1179-89.

23. UK Collaborative HIV Cohort Steering Committee. The creation of a large UK-based multicentre cohort of HIV-infected individuals: The UK Collaborative HIV Cohort (UK CHIC) Study. HIV Med 2004;5:115-24.

24. Abecasis AB, Wang $\mathrm{Y}$, Libin $\mathrm{P}$, et al. Comparative performance of the REGA subtyping tool version 2 versus version 1. Infect Genet Evol 2010;10:380-5.

25. $\mathrm{Ng}$ O'T, Lin L, Laeyendecker $\mathrm{O}$, et al. Increased rate of $\mathrm{CD}^{+}{ }^{+} \mathrm{T}$-cell decline and faster time to antiretroviral therapy in HIV-1 subtype CRF01_AE infected seroconverters in Singapore. PLOS ONE 2011;6:e15738.

26. Huang X, Lodi S, Fox Z, et al. Rate of CD4 decline and HIV-RNA change following HIV seroconversion in men who have sex with men: a comparison between the Beijing PRIMO and CASCADE cohorts. 7 Acquir Immune Defic Syndr 2013;62:441-6.

27. Guo X, Carlin BP. Separate and joint modeling of longitudinal and event time data using standard computer packages. Am Stat 2004;58:16-24.

28. Kaleebu P, French N, Mahe C, et al. Effect of human immunodeficiency virus (HIV) type 1 envelope subtypes $\mathrm{A}$ and $\mathrm{D}$ on disease progression in a large cohort of HIV-1-positive persons in Uganda. 7 Infect Dis 2002;185:1244-50.

29. Baeten JM, Chohan B, Lavreys L, et al. HIV-1 subtype D infection is associated with faster disease progression than subtype A in spite of similar plasma HIV-1 loads. 7 Infect Dis 2007;195:1177-80.

30. Kiwanuka N, Robb M, Laeyendecker O, et al. HIV-1 viral subtype differences in the rate of CD4+ T-cell decline among HIV seroincident antiretroviral naive persons in Rakai district, Uganda. F Acquir Immune Defic Syndr 2010;54:180-4.

31. Cohen MS, Dye C, Fraser C, et al. HIV treatment as prevention: debate and commentary-will early infection compromise treatment-as-prevention strategies? PLoS Med 2012;9:e1001232.

32. Hollingsworth TD, Anderson RM, Fraser C. HIV-1 transmission, by stage of infection. 7 Infect Dis 2008;198:687-93.

33. Touloumi G, Pantazis N, Pillay D, et al. Impact of HIV-1 subtype on CD4 count at HIV seroconversion, rate of decline, and viral load set point in European seroconverter cohorts. Clin Infect Dis 2013;56:888-97.

34. Pantazis N, Morrison C, Amornkul PN, et al. Differences in HIV natural history among African and non-African seroconverters in Europe and seroconverters in sub-Saharan Africa. PLoS ONE 2012;7:e32369.

35. Achhra AC, Amin J. Race and $\mathrm{CD}^{+}{ }^{+} \mathrm{T}$-cell count in HIV prognosis and treatment. Future Virol 2012;7:193-203.

36. Keller M, Lu Y, Lalonde RG, et al. Impact of HIV-1 viral subtype on CD4+ $\mathrm{T}$-cell decline and clinical outcomes in antiretroviral naive patients receiving universal healthcare. AIDS 2009;23:731-7.

37. Anastassopoulou CG, Kostrikis LG. The impact of human allelic variation on HIV-1 disease. Curr HIV Res 2003;1:185-203.

38. Pereyra F, Jia X, McLaren PJ, et al. The major genetic determinants of HIV-1 control affect HLA class I peptide presentation. Science 2010; 330:1551-7.

39. Lin SS, Kelsey JL. Use of race and ethnicity in epidemiologic research: concepts, methodological issues, and suggestions for research. Epidemiol Rev 2000;22:187-202.

40. Easterbrook PJ, Farzadegan H, Hoover DR, et al. Racial differences in rate of CD4 decline in HIV-1-infected homosexual men. AIDS 1996;10:1147-55.

Competing interests: Marina Klein received grants from Merck, the Canadian Institutes of Health Research (CIHR), the National Institute of Health Research, Fonds de recherche du Québec - Santé and ScheringPlough, consulting fees from ViiV, and lecture fees from Bristol-Meyers Squibb and ViiV. She also received fees for the development of educational presentations from Gilead and ViiV. Caroline Sabin received grants from the Medical Research Council of England and Wales during the conduct of the study. Darrell Tan received grants from Gilead and $\mathrm{ViiV}$, consulting fees from Gilead and ViiV, and lecture fees from Abbott, Bristol-Myers Squibb, Gilead, Janssen, Merck and ViiV. Sharon Walmsley received grants, consulting fees, lecture fees, nonfinancial support and fees for the development of educational presentations from Merck, ViiV, Gilead, Abbott, Tibotec, Janssen, Bristol-Myers Squibb and Boehringer Ingelheim. John Gill received a grant from the CIHR and personal fees for being a member of the national advisory boards of Abbvie, Gilead, Merck, Janssen, ViiV and Bristol-Myers Squibb. No competing interests were declared by the other authors.

Affiliations: Division of Infectious Diseases/Chronic Viral Illness Service, Department of Medicine (Klein, Young), Royal Victoria Hospital, McGill University Health Centre, Montréal, Que.; Basel Institute for Clinical Epidemiology and Biostatistics (Young), University Hospital Basel, Basel, Switzerland; Medical Research Council Clinical Trials Unit (Dunn), London, UK; Division of Infectious Diseases and Hospital Epidemiology 
(Ledergerber, Scherrer), University Hospital Zurich, University of Zurich, Zurich, Switzerland; Research Department of Infection and Population Health (Sabin, Cozzi-Lepri, Mocroft), University College London, London, UK; Centre du recherche INSERM U897 - EpidémiologieBiostatistique, Institut de Santé Publique, d'Epidémioloie et de Développement (ISPED) (Dabis), Université Bordeaux, Bordeaux, France; Faculty of Health Sciences (Harrigan, Hogg), Simon Fraser University, Vancouver, BC; Division of Infectious Diseases (Tan), St. Michael's Hospital, Toronto, Ont.; University Health Network (Walmsley), University of Toronto, Toronto, Ont.; Southern Alberta HIV Clinic (Gill), Calgary, Alta.; The Ottawa Hospital - General Campus (Cooper), Ottawa, Ont.; Department of Medicine, Faculty of Medicine (Hogg), University of British Columbia, Vancouver, BC; Department of Medicine (Smaill), McMaster University, Hamilton, Ont.

Contributors: Marina Klein had full access to the data and takes responsibility for the integrity of the data and the accuracy of the reported findings. Jim Young had full access to the dataset, conducted all data analysis and acts as guarantor for the analyses. All of the authors participated in discussions on the design of the study and interpretation of the findings, revised the manuscript, approved the final version submitted for publication and agreed to act as guarantors of the work.

Funding: This work was supported by Fonds de recherche du Québec Santé-Réseau SIDA/maladies infectieuses for the Montreal Chest Immunodeficiency cohort. Marina Klein is supported by a Chercheurnationaux career award from Fonds de recherche du Québec - Santé. The Swiss HIV Cohort Study is supported by the Swiss National Science Foundation (33CS30_134277). The UK Collaborative HIV Cohort Study Study and UK HIV Drug Resistance Database are funded by a program grant from the Medical Research Council UK (G06000337); the views expressed in this manuscript are those of the researchers and not necessarily those of the Medical Research Council. Primary support for EuroSIDA is provided by the European Commission BIOMED 1 (CT94-1637), BIOMED 2 (CT97-2713) and by the 5th Framework
(QLK2-2000-00773), the 6th Framework (LSHP-CT-2006-018632), and the 7th Framework (FP7/2007-2013, EuroCoord No. 260694) programs. Current support for EuroSIDA also includes unrestricted grants by Gilead, Pfizer and Merck. The ANRS CO3 Aquitaine Cohort is funded in part by the French Agence Nationale de Recherches sur le Sida et les hépatites virales, together with the French Institut National de la Santé et de la Recherche Médicale and the Centre Hospitalier Universitaire de Bordeaux (COREVIH Aquitaine and CIC-EC 7). The funders had no role in study design, data collection and analysis, decision to publish or preparation of the manuscript.

Acknowledgements: The authors thank the patients and researchers who contributed to this study: Montreal Chest Institute Chronic Viral Illness Cohort, Montreal, Que.; HAART Observational Medical Evaluation and Research (HOMER) study, Vancouver, B.C. (http://www.cfenet.ubc.ca /research/homer/team); Southern Alberta Clinic Cohort, Calgary, Alta.; Toronto General Hospital, Toronto, Ont.; Ottawa General Hospital, Ottawa, Ont.; McMaster University, Hamilton, Ont.; The UK Collaborative HIV Cohort (UK CHIC) (http:/212.219.75.232/UKCHIC/Study OrganisationUKCHIC.asp); the UK HIV Drug Resistance Database (www .hivrdb.org.uk); Swiss HIV Cohort Study (www.shcs.ch/26-organisation -shcs); the multi-centre study group on EuroSIDA (www.cphiv.dk/Ongoing -Studies/EuroSIDA/Study-group); the Groupe d'Epidémiologie Clinique du Sida en Aquitaine (GECSA) - ANRS CO3 (http://gecsa.isped.ubordeaux2.fr/Presentation.aspx). In particular, the authors wish to acknowledge the contributions of Bernard Masquelier (Centre Hospitalier Universitaire (CHU), Hôpital Pellegrin, Laboratoire de Virologie, Bordeaux, France) who provided virologic data for the ANRS CO3 Aquitaine cohort and participated in revising earlier drafts of the manuscript. Bernard passed away in March 2013. His collegiality and contributions to the field of HIV resistance will be greatly missed.

Supplemental information: For reviewer comments and the original submission of this manuscript, please see www.cmajopen.ca/content/2/4 /E318/suppl/DC1 